\title{
EVALUASI SISTEM PENILAIAN KINERJA PEGAWAI ADMINISTRATIF TETAP UNIVERSITAS ISLAM INDONESIA YOGYAKARTA
}

\author{
Sus Budiharto dan Arief Fahmie \\ Universitas Islan Indonesia
}

\begin{abstract}
Abstrak
Penelitian ini bertujugn untuk mengkaji sistem penilaian kinerja pegawai administratif petap Universitas Islam indonesia (UII) Yogyakarta. Penelitian dilakukan dengan menggunakan metode kualitatif dengan pendekatan studi kasus. Hasil penelitian menunjukkan bahwa (1) Tujuan penilaian kinerja adalah administratif dan evaluatif, (2) Tidak ada proses komunikasi, (3) Alat ukur yang digunakan tidak mempunyai standar yang jelas dan tidak mampu membedakan pegawal yang berprestasi dan lidak berprestasi, (4) Penllal tidak mempunyai ketrampilan sehingga timbul bias yaitu leniency. (5) Tidak ada tindak lanjut hasil penilaian kinerja untuk pengembangan potensi pegawai, (6) Tidak ada umpan balik dari atasan. Berdasar anglisis terhadap masalah tersebut maka direkomendasikan beberapa pemecahan yaitu (1) Tujuan penilaian kineja adalah pengembangan dengan menggunakan dara hasll penilalan kinerja tidak hanya untuk promosi atau kenaikan gaji terapl juga untuk pelatihan atau konseling. (2) Sistem Penilaian Kinerja disosiaisasikan kepada pegawai, (3) Alat ukur yang digunakan mempunyal standar yang Jelas dan dapat membedakan karyawan yang berprestasl dan tidak berprestasi, yøitu Skala Penilaian Grafik dan Peringkatan Altemasi, dan metode penilalan $360^{\circ}$ yailu penilai adalah alasan, rekan sekerja, diri sendiri, dan bawahan, (4) mengadakan rater Error Training dan Frame of Reference Train ing untuk penilai, (5) Pimpinan UII menganalisa sebab-sebab permasalahan kineja dan menyusun program pengembangan potensi pegawai dengan menggunakan hasit penilaian kinerja, (6) Atasan memberikan umpan balik kepada bawahan.
\end{abstract}

Kata-kata Kunci: penilalan kinerja, teniency, umpan balik, Metode $360^{\circ}$.

\section{PENDAHULUAN}

$\mathbf{U}$ niversitas Islam Indonesia (UII) Yogyakarta merupakan universitas swasta yang tertua di Indonesia. Sampai tahun akademi 2000/2001 jenjang program pendidikan yang ada di Ull adalah jenjang Program D3 dengan 1 program studi meliputi 3 jurusan, Jenjang Program S1 dengan 7 Fakultas meliputi 18 jurusan, Jenjang Program S2 (Pascasarjana) dengan
4 program Magister, dan Jenjang Program S3 (Doktor) meliputi bidang llmu Ekonoml dan IImu Hukum. Animo masyarakat untuk menyekolahkan putra-putrinya ke universitas ini dafi tahun ke tahun semakln meningkat. Lebih dafi 10.000 calon mahasiswa dari seluruh Indonesia (bahkan beberapa mahasiswa dari luar negeri) setiap tahun bersaing untuk mendapatkan kursi di 8 Fakultas di 
lingkungan Ult. Tahun ajaran 2000/2001 jumlah mahasiswa $(\mathrm{D} 3, \mathrm{~S} 1, \mathrm{~S} 2, \mathrm{~S} 3)$ tercatat 20.084 mahasiswa yang tersebar dalam berbagai fakultas yang ada. Adapun jumlah sarjana/magister/diploma yang diluluskan sampai tahun ajaran 2000/2001 sebanyak 25.999 orang. Jumlah dosen tetap sebanyak 438 dan jumlah pegawai administratiftetap sebanyak405 ( $M$ mw uiliac,jd, 2002).

Pengembangan UII sudah termuat secara lengkap dalam Rencana induk Pengembangan (RIP) Utl mengenal rencana jangka pendek, jangka menengah, dan jangka panjang, yang mencakup aspek-aspek pengentaangan akademik maupunpengembangan fisk. Pengembangan akademik mencakup aspek-aspek pengembangan fakultas, jurusan dan program studi; pengembangan strata pendidikan S1, S2, S3; pengembangan jumlah mahasiswa, tenaga pengajar dan tenaga administrasi; dan pengembangan organisasi (wrw, uit.ac,id, 2002).

Di usia ke-58, Uli memasuki babak bau untuk melakukan evaluasi menyeluruh, dengan prioritas utama pada sektor sumber daya manusia terutama bagian admisnitratif. Selama ini pegawai administratif konon memang menjadi persoalan yang cukup "serius", dalam menunjang keberhasilan pengelolaan organisasi UII, terutama standar kualitasnya (Warta Kampus, 2001). Pegawai administratif di Ull terbagi menjadi 2 yaitu yang tetap dan kontrak. Pegawai administratif yang dimaksud di atas adalah pegawai administratif tetap.

Peningkatan kualitas pegawai administratif tetap UII dimulai pada sistem penilalan kinerjanya. Penilaian kinerja menjadi penting disebabkan oleh: (a) pegawai admisnistratif tetap merupakan tulang punggung proses administrasl karena mereka yang akan menduduki jabatan struktural; (b) penilaian bahwa kinerja pegawai administratif tetap adalah buruk masih didasarkan pada penilaian yang bersifat awam sehingga dibutuhkan sistem yang dapat dipertanggungiawabkan secara ilmiah; (c) sistem penilaian kinerja pegawai administratif tetap yang ada selama ini dinilai belum efektif dan akurat karena selama inl aktivitas penilaian kinerja hanya dilakukan untuk rutlnisitas saja; (d) program peningkatan kualitas kinerja pegawai administratif tetap tidak dapat dilakukan dalam program yang terencana karena data tentang kualitas kinerja tidak akurat.

Penilaian kinerja memang merupakan salah satu kegiatan pokok dalam pengembangan sumber daya manusia. Dresler (1997) menyatakan bahwa penilaian kinerja berfungsi untuk promosi dan keputusan mengenai gaji, akan tetapi idealnya juga berfungsi untuk mengelola kinerja dengan memberikan dasar bagi suatu analisis berhubungan dengan kinerja sesorang karyawan dan langkah-langkah yang akan diambil untuk mempertahankan atau mengubahnya.

Sebagai institusi pendidikan yang besar dan harus bersaing di iklim yang kompetitif maka Universitas Islam Indonesia perlu terus merancang dan melaksanakan progam pengembangan sumber daya manusla. Berdasarkan hal tersebut maka peningkatan kualitas kinerja pegawai administratif tetap Universitas Islam Indonesia penlu dikaji lebih jauh dengan bertitik tolak pada evaluas| terhadap sistem penilaian kinerjanya.

\section{DASARTEORI}

\section{A. Proses dan Manfaat Panilalan KInerja}

Penilaian kinerja merupakan salah satu aktlvitas yang penting dalam manajemen sumber daya manusia. Dipboye, Smith, dan Howell (1994) menyatakan bahwa penilaian kinerja adalah suatu proses untuk menilal kinerja tebaru dari pegawal dan mengevaluasinya berdasar sejumlah kriteria. 
Sebagai suatu proses maka penilaian kinerja mempunyai beberapa aktivitas yang saling berkaitan satu dengan yang lain. Dresler (1997) mengemukakan proses penilaian kinerja adalah sebagai berikut (1) Mendefinisikan pekerjaan yaitu memastikan bahwa atasan dan bawahan sepakat tentang tugas-tugasnya dan standar jabatan, (2) Menilai kinerja yaitu membandingkan kinerja bawahan dengan standar-standar yang telah ditetapkan dengan menggunakan formulir penilaian, dan (3) Umpan balik yaitu pembahasan kinerja dan kemajuan bawahan dan pembuatan rencana-rencana pengembangan lebih lanjut. Konsep lain dikemukakan Carroll dan Schneir dalam Gomez-Meija, dkk (2001) yang mengemukakan bahwa proses perilaian kinerja adalah:

Identification $\rightarrow$ Measuriement $\rightarrow$ Management

Identification yaitu penentuan wilayah kerja untuk dinilai. Measurement yaitu penentuan pegawai mempunyai kinerja yang baik atau buruk. Management yaitu mengembangkan hasil penilaian kinerja dengan orientasi ke masa depan d mana phak manajemen mendorong pegawai untuk menjadikan potensinya menjadi prestasi dan menyusun sistem yang kondusif untuk tujuan tersebut.

Dresler (1997) mengemukakan bahwa penilaian tradisional tidak membantu dalam mengelola kinerja dan sesungguhnya bisa merusak. Kebanyakan sistem penilaian kinerja tidak memotivasi pegawai, juga tidak memandu pengembangan kinerja. Sistem penllaian juga dianggap menyebabkan konflik antara atasan dan bawahan dan mengarah ke perilaku yang disfungsional, aspek yang diukur sering bersifat personal, dan orang tidak menyukai untuk dinilai kejujuran, integritas, kerja tim, kerjasamanya.
Demings dakm Dresler (1997) menyatakan menyetujui penghilangan penilaian kinerja karena organisasi adalah satu sistem dari bagian-bagian yang saling berhubungan sehingga sulit untuk menyimpulkan bahwa kinerja seorang pegawai adalah baik atau buruk. Walaupun demikian, dia tidak menawarkan altematif pernecahannya tentang bagaimana keadilan terhadap orang yang dibayar sama tetapi dengan kinerja yang berbeda

Sebenamya banyak sekali manfaat penilaian kinerja dalam pengembangan sumber daya manusia. Penilaian kinerja masih digunakan untuk formalitas, rutinitas, atau pengambilan keputusan personalia. Hasil dari proses penilaian kinerja lalu digunakan untuk pengambilan keputusan personalia, seperti penentuan gaji, promosi, mutasi, penugasan, atau pemutusan hubungan kerja (Dipboye, Smith, dan Howell, 1994). Sebenamya penilaian kinerja dapat digunakan untuk pengembangan sumber daya manusia dalam arti yang luas. Dresler (1997) mengemukakan penilaian kinerja berfungsi untuk promosi dan keputusan mengenai gaji, akan tetapi idealnya juga bertungsi untuk peran mengeiola kinerja dengan memberikan dasar yang jelas untuk suatu analisis terhadap kinerja sesorang pegawai dan langkah-langkah yang hendaknya diambil untuk mempertahankan atau meningkatkannya.

Keuntungan melaksanakan penilaian kinerja tampaknya lebih besar daripada kerugiannya. Kerugian yang muncul pada proses penilaiarı kinerja tidak serta merta menghilangkan penilaian kinerja dalam pengelolaan sumber daya manusia suatu organisasi. Sesual dengan yang dikemukakan Dresler (1997) bahwa jalan keluarnya adalah menciptakan sistem penilaian kinerja yang efektif sehingga memungkinkan untuk mengelola kinerja dalam lingkungan yang berorientasi tim dan mutu. 


\section{B. Metode-metode Penilaian Kinerja}

Terdapat bermacam-macam metode pengukuran dalam proses penilaian kinerja. Dresler (1997) mengklasifikasikan metodemetode dalam penilaian kinerja sebagai berikut (1) Metode Skala Penilaian Grafik. Teknik ini menggunakan skala yang menggunakan sejumlah ciri dan jangkauan kineja untuk masing-masing tugas. Pegawai dinilai dengan skor yang paling sesuai dengan tingkat kinerja untuk masing-masing aspek. (2) Metode Peringkatan Altemasi. Teknik ini dilakukan dengan membuat peringkat pegawai dari yang terbaik sampai kepada yang terjelek berdasarkan ciri tertentu. (3) Metode Perbandingan Berpasangan. Teknik ini dilakukan dengan membuat peringkat bag pegawai dengan menggunakan tabel dari semua pasangan pegawai yang ada dan menilai pegawai mana yang lebih baik dari pasangannya. (4) Metode Distribusi Paksa. Metode ini mirip dengan pemeringkatan pada sebuah kurva nomal. Kategori kinerja dari yang tinggi sampai dengan rendah ditentukan persentasenya. (5) Metode Insiden Kritis. Metode ini dilakukan dengan membuat satu catatan tentang contohcontoh yang luar biasa atau tidak dinginkan dari perlaku yang berhubungan dengan keja seseorang pegawai dan melihat kembali bersama pegawai pada waktu yang telah ditentukan sebelumnya. (6) Skala Penilajan Berjangkarkan Penilaian. Metode ini bertujuan mengkombinasikan manfaat dari insiden kritis dan penilaian berdasarkan kuantitas dengan menjangkarkan skala berdasarkan kuantitas pada contoh-contoh naratif spesifik dari kinerja yang baik dan yang jelek. (7) Metode Manajemen Berdasarkan Sasaran. Metode ini meliputi penetapan tujuan khusus yang dapat diukur bersama dengan pegawai dan selanjutnya secara berkala ditinjau kemajuan yang dicapai.
Klasifikasi yang lain tentang metodemetode pengukuran dalam proses penilaian kinerja dikemukakan oleh Gomez-Meija, dkk (2001). Gomez-Meija, dkk mengklasifikasikan alat ukur untuk penilaian kinerja berdasarkan tipe keputusan yang digunakan dan fokus pengukuran. Berdasarkan tipe keputusan yang digunakan terdapat 2 tipe keputusan yaitu relatif dan absolut. Tipe relatif akan mengakibatkan format penilaian yang mengharuskan atasan untuk membandingkan kinerja pegawai dengan pegawai lain yang mengerjakan tugas yang sama, misalnya teknik metode berpasangan Tipe absolut akan mengakibatkan format penilaian yang mengharuskan atasan membuat keputusan tentang kinerja pegawal berdasar pada standar kinerja yang ada, misalnya teknik BARS. Berdasarkan fokus pengukuran terdapat 3 fokus pengukuran yaitu sifat, perilaku, atau keluaran kinerja. Pada teknik yang befokus pada sifat akan mengharuskan atasan memutuskan tentang karakteristik pegawai yang cenderung tetap, misalnya loyal, dan sebagainya. Fokus pada perilaku akan mengharuskan atasan untuk mengukur perilaku keja pegawai, misalnya teknik BARS. Fokus pada keluaran kinerja berarti mengukur hasil prestasi pegawai, misalnya Manajemen Berdasarkan Sasaran.

$\mathrm{Hal}$ penting lainnya dalam proses penilaian adalah penilai. Penilaian kinerja dalam perspektif tradisional memberikan porsi yang lebih banyak kepada atasan. Perspektif yang kontemporer tidak demikian. Dresler (1997) mengemukakan bahwa penilai dalam penilaian kinerja adalah (1) Atasan langsung. Penilai dari atasan langsung relatif mudah dilaksanakan dan sangat logis karena biasanya mengobservasi dan mengevaluasi kinerja bawahannya, serta bertanggungjawab terhadap kinerja Orang tersebut. (2) Rekan sekerja. Penilai dari rekan sekerja dapat menjadi efektif dalam meramalkan keberhasilan ma- 
najemen masa depan. Masalahnya adalah logrolling yang terjadi ketika semua rekan kerja kompak untuk menilai tinggi terhadap yang lain. (3) Komite penilaian. Komite ini biasanya terdiri cari atasan langsung dan 3 atau 4 supervisor lainnya. Dasar pemikirannya adalah penilaian gabungan cenderung menjadi lebih handal, jujur, dan absah. (4) Diri sendiri. Penilai terhadap kinerja dapat dilakukan oleh diri sendirinya. Permasalahan utamanya adalah bahwa seseorang cenderung untuk menilaj lebih tinggi dari keadaan yang sebenamya. (5) Bawahan.

Menilaj kinerja atasan langsung sering disebut dengan umpan balik dari bawah Hal ini akan membantu manajer puncak mendiagnosis gaya kepemimpinan, mengidetifikasi masalah-masalah pegawai yang potensial, can mengambil tindakan perbaikan dengan para pimpinan sehingga lebih bermanfaat untuk tujuan pengembangan daripada tujuan evaluatif. (6) Umpan balik $360^{\circ}$. Penilaian kinerja dengan umpan balkk $360^{\circ}$ menggunakan informasi kinerja yang dikumpulkan "dari sekeliling" seorang pegawai, yaitu dari para atasan langsung. bawahan, rekan kerja, dan pelanggan internal atau ekstemal. Umpan balik umumnya lebih digunakan untuk pelatihan dan perigembangan dari pada untuk peningkatan upah.

Saat ini penilai yang dipilih adalah umpan balik $360^{\circ}$ karena tujuan pengembangan lebih diutamakan daripada sekedar tujuan administratif dan evaluatif. Secara lebih terperinci penilaian kinerja dengan umpan balik $360^{\circ}$ ditakukan dengan cara (Millman, dkk dalam Dipboye, dkk, 1994): (1) Top manajemen mengkomunikasikan tujuan dan kebutuhan terhadap model penilaian $360^{\circ}$. (2) Pegawai dan para atasan terlibat dalam pengembangan kriteria penilaian dan proses penilaian. (3) Pegawai dilatih tentang cara memberi dan menerima umpan balik. (4)
Pegawai diberitahu tentang proses dan alat ukur dari model penilaian $360^{\circ}$. (5) Model penilaian $360^{\circ}$ dilaksanakan uj coba di salah satu bagian organisasi. (6) Manajemen secara kontinyu mengarahkan aktivitas organisasi kepada tujuan penlaian $360^{\circ}$ dan merubah prosesnya bila pertu.

\section{OPTIMALISASI SISTEM PENILAIAN KINERJA}

Penilaian kinerja mempunyai problem tersendiri yang dapat menganggu pihakpihak yang terkait dalam proses penilaian kinerja untuk mencapai hasil yang optimal. Dipboye, Smith, dan Howell (1994) menekankan masalah utamanya yaitu: Apa yang sebaiknya dievaluași? Bagaimana mengevaluasi dengan akurat? Pertimbangan yang harus dilakukan adalah reliabilitas, praktis, relevansi, keadilan, dan mampu membedakan pegawai yang mempunyai kinerja baik dan yang buruk.

Konsep yang lebih terperinci dikemukakan oleh Dresler (1997) yang menyatakan bahwa masajah umum dalam penilaian kinerja adalah (1) Tidak memiliki standar. Penilaian kinerja yang tidak menggunakan standar akan membuat hasil penilaian yang tidak objektif karena hanya berdasar dugaan saja. (2) Standar yang subjektif. Standar sebaiknya ditetapkan dengan menganalisis hasil pekerjaan untuk memastikan bahwa standar-standar itu berhubungan dengan pekerjaan. (3) Standar yang tidak realistis. Tujuan dari penetapan standar adalah potensi memotivasi pegawai agar berprestasi. Standar-standar yang masuk akal dan menantang itu paling berpotensi untuk memotivasi.(4) Ukuran suatu kinerja yang jelek. Contoh-contoh tentang ukuran kinerja yang dapat diukur baik kuantitatif, misalnya penjualan perbulan, maupun ukuran kualtatati, seperti proyek yang diselesaikan dan tidak diselesaikan. (5) Kesalahan penilai. 
Kesalahan penilai dalam proses penilaian kinerja antara lain bias, efek halo, kesalahan konstan, kecenderungan sentral, dan ketakutan akan konfrontasi dari pihak yang dinilai. (6) Umpan baik yangjelek terhadap pegawai. Standardan atau penilaian harus dikomunikasikan kepada pegawai agar evaluasi kinerja dapat dilakukan dengan efektif. (7) Komunikasi yang buruk. Proses evaluași itu dihalangi oleh komunikasi yang negatif, seperti kaku, pembelaan diri, dan pendekatan yang tidak bersifat mengembangkan. (8) Kegagalan menerapkan data evaluasi. Kegagalan untuk menggunakan evaluasi dalam pengambilan keputusan personalia dan pengembangan pegawai menjadikan tujuan utama penilaian kinerja menjadi kabur.

Masalah-masalah yang lebih spesifik juga muncul dalam penilaian. Permasalahan ini berada dalam pelaksanaan pengukuran. Dresler (1997) menekankan bahwa masalah utama dalam pelaksanaan pengukuran adalah (1) Standar kinerja yang tidakjelas sehingga terialu terbuka terhadap interpretasi, misalnya baik, tidak memuaskan, sedang. (2) Efek halo yang terjadi bila penilaian seorang atasan terhadap bawahan di satu aspek membuat bias pada aspek lain. (3) Kecenderungan sentral d mana kecenderungan untuk menilai semua pegawai dengan cara yang sama, seperti menilai pada tingkat rata-rata, sedangkan severity adalah kecenderungan semua pegawai dinilai negatif dan leniencyadalah kecenderungan semua pegawai dinilai positif. (4) Terlalu keras atau longgar merupakan masalah yang terjadi ketika seorang atasan cenderung untuk menilal semua bawahan terlalu tinggi atau rendah. (5) Prasangka merupakan kecenderungan yang dipengaruhi perbedean individual seperti usla, ras, dan jenis kelamin, yang mempengaruhi tingkat penilaian atasan terhadap pegawai.
Berbagai kemungkinan-kemungkinan masalah dan hambatan yang timbul dalam proses penilaian kinerja. Dari berbagai masalah dan hambatan dapat disimpulkan bahwa hal tersebut terjadi pada alat atau metode yang digunakan, penilai, komunikasi, atau budaya organisasi; dan teriadi dalam proses pra-pengukuran, pengukuran, maupun pasca pengukuran.

Berdasar komponen yang dapat menjad hambatan dan masalah dalam penilaian kinerja maka cara untuk mengoptimalkan proses penilaian kinerja adalah (f) Menentukan dan mengkomunikasikan tujuan penilaian dengan tepat. Dipboye, Smith, dan Howell (1994) mengemukakan bahwa penilaian yang bertujuan untuk eksperimental, misalnya validasi alat tes atau pelatihan, berkurang efek Ieniency-nya dan lebih akurat daripada tujuan yang admnistratif, misalnya kenaikan gaji. Penilaian untuk mengembangkan dan meningkatkan kinerja memberikan daya pembeda yang lebih besar daripada untuk menentukan kenaikan gaji.

Halachmi dalam Riyono (1998) menambahkan bahwa untuk meningkatkan efektivitas penilaian kinerja maka perlu mengubah dari tujuan dokumentasl dan evaluasi kinerja pegawai menjadi mengukur kerjasama antara atasan dengan bawahan. (2) Mernilih alat penilaian yang tepat. Riyono (1998) mengemukakan bahwa terdapat 5 tipe alat penilaian, yaitu (a) Ambiguous com parison standard d mana standar kinerja dinyatakan dalam bentuk terlalu umum dan kurang mempunyai definisi operasional. (b) Internal comparison standard di mana standar kinerja djbandingkan denga dirinya sendiri. (c) Absolute comparison standard di mana standar kinerja dibandingkan dengan ukuran objektlf. (d) Relative comparison standard di mana standar kinerja dibandingkan dengan orang lain di kelompoknya. (e) Multiple comparison stan- 
darddi mana standar kinerja menggunakan lebih dari satu standar. (f) Hasil yang terbaik. bila menggunakan absolute comparison standard dan multiple comparison standard. (3) Memberikan pelatihan untuk menghilangkan kesesatan penilaian yang dilakukan penilai. Riyono (1998) mengemukakan bahwa beberapa metode pelatihan dapat diterapkan untuk mengendalikan dan mengurangi kendala dalam proses penilaian kinerja yaitu (a) Rater aror training. Berguna untuk mengurangi efek penilaian seperti hallo dan feniency. Pelatihan membimbing peserta untuk mengenali efek penilaian dan mendorong untuk menghindarinya dalam proses penilaian. (b) Performance dimension training. Berhubungan dengan aspek kinerja yang digunakan dalam penilaian. Jika penilai mengenali dan menggunakan dimensi yang penting dan dibutuhkan, akan mendorong keakuratan dalam penilaian. (c) Frame of reference training. Pelatihan ini dilakukan dengan memberikan atasan contoh-contoh fiktif dari kineria pegawai (secara tertulis atau visual), menugaskan kepada atasan untuk mengevaluasi kinerja tadi, dan memberitahu kepada atasan apa yang sebaiknya erjadi dan clakukan (GomezMeija, dkk, 2001). (d) Behavioral observation training. Fokus pelatihan ini adalah mengurang efek on-linedari ovaluasi. Penilai dilatih untuk membedakan antara observasi terhadap perilaku dan evaluasi terhadap perilaku. Proses observasi hanus dipisahkan dengan proses evaluasi. Dalam proses observasi, penilai sebaiknya hanya melihat dan mengambil catatan pada perilaku yang dinilai, atau disebut proses pengumpulan data. Setelah data dikumpulkan, lalu proses evaluasi dimulai dengan menganalisa data dan memutuskan kualitas dan kuantitas perilaku yang berhubungan dengan kinerja. Prose pelatihan juga menggunakan pengukuran ingatan, termasuk kemampuan mendeteksi dan pengaruh persepsi terhadap peristiwa-peristiwa perilaku yang spesifik. Dalam pelatihan ini, pengukuran bukan pada akurasi rating tetapi pada akurasi observasi. Lebih akurat observasi maka lebih efektif evaluasinya. (4) Memanfaatkan hasil penilaian kinerja untuk pengembangan pegawai. Gomez-Meija, dkk (2001) mengemukakan bahwa atasan yang mampu meningkatkan kinerja secara efektif dengan memanfaatkan penilaian kinerja akan bertindak sebagai berikut (a) Mengeksplorasi sebab-sebab permasalahan. (b) Memberikan perhatian langsung terhadap penyebab masalah. (c) Menyusun rencana kerja dan memberdayakan pegawai untuk memper oleh solusi yang tepat. (d) Memberi umpan balik yang efektif. (5) Menghilangkan faktor eksternal, seperti keterkaitan penilaian dengan upah, tekanan serikat pekerja, kondisi politik organisasi, dan keterbatasan waktu.

\section{METODE PENELITIAN}

Metode penelitian yang dilakukan adalah metode kualitatif dengan pendekatan studi kasus. Lokasi penelitian dilakukan d organisasi tingkat universitas dan di tingkat takultas, yaitu Fakultas Psikologi Ull. Hal ini disebabkan kedua organisasi tersebut dapat mewakili seluruh organisasi d tingkat universitas maupun fakultas.

Metode pengambilan data dilakukan dengan wawancara dan dokumentasi. Wawancara dilakukan terhadap Pembantu Rektor II, Kepala Bro Pengembangan SDM, Pembantu Dekan If F. Psikologi Uli, Kepala Bagian Akademik F. Psikologi UII, dan pegawai administratif tetap. Dokumentasi yang digunakan adalah lembar penilaian kinerja pegawai admisnitratif tetap UII dan dokumen Sistem ISO 9002 UII. 


\section{HASIL PENELITIAN DAN PEMBAHASAN}

Pegawai administratif tetap Ull ditugaskan di Kantor Pusat UII, Program D3, S1, S2, S3, maupun lembaga-lembaga lainnya di Ull. Jumlah seluruh pegawai administratif tetap adalah 405 orang. Pegawai administratif tetap mempunyai hak yang lebih daripada pegawai administratif kontrak, antara lain berhak menduduki jabatan struktural kepala bagian dan kepala biro.

Penilaian kinerja bagi pegawal administratif tetap dilakukan sebanyak 2 tahun sekali. Pada tahun ke-2, penilaian kinerja dilakukan untuk kenaikan berkala dengan konsekuensi pada kenaikan tunjangan yang diterima, sedangkan pada tahun ke-4, penilaian kinerja dilakukan untuk kenaikan golongan bagi yang masih mempunyai kesempatan dengan ditambah menjalani tes tertentu.

Penilaian dilakukan oleh atasan langsung dengan menggunakan lembar perilaian yang telah ditentukan. Peraturannya adalah bahwa bila terdapat 1 nilai $\mathrm{C}$ atau kurang dari $\mathrm{C}$ d salah satu aspek, maka pegawai terse but dinyatakan tidak lulus dan ditunda kenaikannya selama 1 tahun. Pegawai tersebut akan dinilai kembali setahun kernudian dan ditentukan apakah mengalami kenaikan berkala atau tidak. Bila terdapat pegawai yang prestasinya sangat buruk maka Pimpinan Fakultas atau lembaga sejenis, akan menginim pegawai tersebut ke Pimpinan Universitas. Pimpinan Universitas biasanya menempatkan pegawai tersebut d tempat lain. Sampai saat ini sangat jarang terdapat pegawai yang di-PHK.

Penilaian kinerja untuk pegawai yang mempunyai jabatan struktural dan tidak mempunyai, dilakukan dengan lembar dan peraturan yang sama. Untuk pegawai dengan jabatan kepala bagian, penilaian dilakukan oleh Pembantu Dekan atau Kepata Biro sesuai dengan struktur organisasi di tempat kerja masing-masing.
Berdasarkan data yang diperoleh maka dapat dirumuskan permasalahan dalam sistem penilajan kinerja pegawai administratif tetap Universitas Islam indonesia adalah (a) Saat pra-pengukuran. Pada saat sebelum pengukuran, permasalahan yang timbul adalah tujuan penilaian kinerja, pemilihan alat ukur, dan komunikasi. Tujuan selama ini adaiah tujuan administratif dan evaluatif sehingga kurang memperhatikan tujuan pengembangan. Alat ukur yang digunakan tidak mempunyai standar yang jelas dan tidak mampumembedakan pegawai yang ber prestasi dan tidak berprestasi. Komunikasi juga tidak dilakukan karena berslfat rutinitas sehingga tujuan penilalan kinerja menjadi tidak jelas. (b) Saat pengukuran. Pada saat pengukuran, permasalahan yang timbul adalah penilai dan budaya organisasi. Penilai tidak mempunyai ketrampilan dalam menilai sehingga timbul bias dalam menilai. Budaya organisasi mengakibatkan atasan cenderung melindungi pegawai yang berprestasi bunk dan tekanan bawahan terhadap atasan dalam proses penilaian kinerja. (c) Saat pasca-pengukuran. Pada saat setelah pengukuran, permasalahan yang timbul adalah umpan balik dan menindaklanjuti data penilaian kinerja. Umpan balik tidak dilakukan sehingga pegawai hanya mengetahul hasil akhirnya yaitu apakah hasilnya baik atau buruk. Tindak lanjut benpa pengembangan potensi pegawai tidak dlakukan. Jika terdapatprogram pengembargan potensi maka pelaksanaannya tidak berdasar data hasil penilaian kinerja.

\section{KESIMPULAN DAN SARAN}

\section{A. Kesimpulan}

Berdasarkan data yang dikumpulkan dan intervensi yang dilakukan maka dapat ditarik kesimpulan sebagal berikut: 
1. Permasalahan yang timbul dalam proses penilaian kinerja untuk pegawai administratif tetap Universitas Islam indonesia Yogyakarta adalah:

a. Pada saat sebelum pengukuran, permasalahan yang timbul adalah tujuan penitaian kinerja, pemilihan alat ukur, dan komunikasi.

b. Pada saatpengukuran, pemasalahan yang timbul adalah penilai dan budaya organisasi.

c. Pada saat setelah pengukuran, permasalahan yang timbul adalah umpan balik dan menindaklanjuti data penilaian kinerja.

2. Berdasarkan analisis terhadap permasalahan yang ada maka Intervensi untuk mengatasinya adalah sebagai berikut:

a. Intervensi yang telah dilakukan yang terdiri dari 2 intervensi, yaitu penyusunan konsep sistem penilaian kinerja dan sosialisasi. Penyusunan konsep sistem penilaian kinerja dilakukan dengan mengevaluasi kelemahan sistem penilaian kinerja yang selama ini digunakan dan menyusun konsep sistem yang lebih sempuma. Kedua intervensi tersebut terjadi pada proses pra-pengukuran.

b. Intervensi yang direkomendasikan yang terdiri dari 2 intervensi, yaitu pelaksanaan penilaian kinerja dan tindak lanjut penilaian kinerja. Pelaksanaan penilaian kinerja dilakukan dengan mengadakan pelatihan bagi penilai dan pengukuran kinerja, sedangkan tIndak lanjut penilaian kinerja dilakukan dengan menganalisa sebab-sebab permasalahan kinerja, menyusun rencana kerja dan memberdayakan pegawai untuk memperoleh solusi yang tepat, dan pemberian umpan balik.

\section{B. Saran}

Berdasarkan data yang diperoleh dan intervensi, bak yang telah dilakukan maupun yang direkomendasikan, maka saran yang diberikan adalah:

1. Perlunya perbaikan sistem penilalan kinerja yang komprehensif yaitu:

a Saat pra-pengukuran:

* Tujuan penilaian kinerja adalah pengembangan dengan menggunakan data hasil penilaian kinerja tidak hanya untuk promosi atau kenaikan gaji tetapi juga untuk pelatihan atau konsellng.

* Sistem Penilaian Klnerja disosialisaskan kepada pegawal.

* Alat ukur yang digunakan mempunyal standar yang jelas dan dapat membedakan karyawan yang berprestasi dan tidak berprestasi, yaitu Skala Penilaian Grafk dan Peringkatan Altemasi, dan metode penilalan $360^{\circ}$ di mana penilai adalah atasan, rekan sekerja, diri sendiri, dan bawahan.

b. Saat pengukuran:

* Alat ukur yang dipakal adalah Peringkatan Altemasi sehingga menghilangkan bias leniency serta metode penilaian $360^{\circ}$.

* Menggunakan metode penilaian $360^{\circ}$ dan mengadakan Rater Enor Trainingdan fiame of Reforence Training untuk penilai.

c. Saat pasca pengukuran:

* PImpinan Ull menganalisa sebab-sebab permasalahan kinerja dan menyusun program pengembangan potensi pegawai dengan menggunakan hasil penilaian kinerja.

* Atasan memberikan umpan balik kepada bawahan. 
3. Penelitian berikutnya dapat menelaah lebh lanjut proses pengukuran dan pasca pengukuran yang disarankan sehingga dapat diketahui efektivitas dari upaya penyempumaan sistem perilaian kinerja yang telah dilakukan.

\section{DAFTAR PUSTAKA}

. 2002. http / /www uli.ac. id.

1996. Ery Arifuddin (editor). Setengah Abad UII. Yogyakarta: UII Press.

Desslerr. G. 1997. Manajemen SumberDaya Manusia Jilid 2. Alih bahasa: Benyamin Molan. Jakarta. PT Dadi Kayana Abadi.
Dipboye, R.L., Smith, C.S. Howell, W.C. 1994. Understanding industrial and Organizational Psychology: An integrated Approach. Forth Worth:Harcourt Brace College Publishers.

Gomez-Meija, L.R. Balkin, D.B., Cady, R.L. Managing Human Resource. $3^{\text {th }}$ ed New Jersey: Prentice-Hall.

Pumamasari, A. 2001. Laporan Praktek Kerja Bidang Psikologi Industri dan Organisasi di KOPMA UGM. Laporan (tidak diterbitkan). Yogyakarta: F. Psikologi UGM.

Riyono, B. 1998. Rethinking The Performance Appraisal. Psikologika. Volume 5, halaman 5-12.

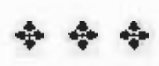

